Boise State University

ScholarWorks

Biology Faculty Publications and Presentations

Department of Biological Sciences

7-1-2013

Increase in ACC Oxidase Levels and Activities

During Paradormancy Release of Leafy Spurge (Euphorbia Esula) Buds

Wun S. Chao

USDA-Agricultural Research Service

Marcelo Serpe

Boise State University

Jeffrey C. Suttle

USDA-Agricultural Research Service

Ying Jia

Texas A \& M University - Kingsville

This is an author-produced, peer-reviewed version of this article. The final publication is available at www.springerlink.com. Copyright restrictions may apply. DOI: 10.1007/s00425-013-1887-z.

This is an author-produced, peer-reviewed version of this article. The final publication is available at www.springerlink.com. Copyright restrictions may apply. DOI: [DOI \#] 


\title{
Increase in ACC Oxidase Levels and Activities During Paradormancy Release of Leafy Spurge (Euphorbia Esula) Buds
}

\author{
Wun S. Chao \\ USDA-ARS \\ Fargo ND 58105, USA \\ Marcelo Serpe \\ Department of Biological Sciences \\ Boise State University, Boise, ID 83725, USA
}

\author{
Jeffrey C. Suttle \\ USDA-ARS \\ Fargo ND 58105, USA \\ Ying Jia \\ National Natural Toxins Research Center \\ Texas A\&M University-Kingsville \\ Kingsville, TX 78363, USA
}

Corresponding author: Wun S. Chao

E-mail:wun.chao@ars.usda.gov

Telephone: 701-239-1256

Fax: 701-239-1252

\begin{abstract}
The plant hormone ethylene is known to affect various developmental processes including dormancy and growth. Yet, little information is available about ethylene's role during paradormancy release in underground adventitious buds of leafy spurge. In this study, we examined changes in ethylene evolution and the ethylene biosynthetic enzyme ACC oxidase following paradormancy release (growth induction). Our results did not show an obvious increase in ethylene during bud growth. However, when buds were incubated with $1 \mathrm{mM} \mathrm{ACC}$, ethylene levels were higher in growing than non-growing buds, suggesting that the levels of ACC oxidase increased in growing buds. Real-time qPCR indicated that the transcript of a Euphorbia esula ACC oxidase (Ee-ACO) increased up to 3-fold following growth induction. In addition, a 2.5- to 4-fold increase in ACO activity was observed 4 days after decapitation, and the Ee-ACO accounted for as much as $40 \%$ of the total ACO activity. Furthermore, immunoblot analyses identified a 36-kD Ee-ACO protein that increased in expression during bud growth. This protein was highly expressed in leaves, moderately expressed in crown buds, stems and meristems, and weakly expressed in roots and flowers. Immunolocalization of Ee-ACO on growing bud sections revealed strong labeling of the nucleus and cytoplasm in cells at the shoot apical meristem and leaf primordia. An exception to this pattern occurred in cells undergoing mitosis, where labeling of Ee-ACO was negligible. Taken together, our results indicate an increase in the levels of Ee-ACO during paradormancy release of leafy spurge that was not correlated with an increase in ethylene synthesis.
\end{abstract}

Keywords: ACC oxidase, Dormancy, Ethylene, Euphorbia, Leafy spurge, Pardormancy release, Underground adventitious buds

Abbreviations: ACO, ACC oxidase; Ee, Euphorbia esula; GST, glutathione S-transferase; MBP, maltose-binding protein

\section{Introduction}

Ethylene participates in the regulation of multiple physiological and developmental processes in plants including fruit ripening, seed germination, flowering, abscission, senescence, and responses to stress (Bleecker and Kende 2000). The ethylene signaling pathway has been well characterized. This signaling pathway is known to interact with other phytohormones and signals such as glucose and light (Chen et al. 2005; Stepanova and Alonso 2009). Ethylene affects plant growth by acting as an inhibitor or stimulator based on its concentration. Pierik et al. (2006) explained ethylene action as "biphasic" in that plant growth is stimulated at low concentrations and inhibited at high concentrations. Many key components (receptors, kinases, and transcription factors) of the ethylene signal transduction pathway leading 
from initial hormone perception to transcriptional regulation were identified based on genetic screens of mutant Arabidopsis seedlings (Chen et al. 2005). Ethylene is perceived by a family of membrane bound receptors that are negative regulators of ethylene signaling. The ethylene signaling pathways and their regulatory networks have been well examined and reported (Kendrick and Chang 2008; Stepanova and Alonso 2009; Zhao and Guo 2011).

Ethylene is synthesized through the production of S-adenosylmethionine (SAM) from the amino acid methionine. SAM is then converted to 1-aminocyclopropane-1-carboxylic acid (ACC) by ACC synthase, and ACC is further oxidized to ethylene in the presence of ACC oxidase (ACO) (Dorling and McManus 2012). After ACC is released from SAM, the methylthio group and the ribose moiety from the remaining methylthioadenosine are recycled to replenish methionine levels to sustain high rates of ethylene synthesis through a recycling pathway known as the Yang Cycle (Bradford 2008).

ACOs are encoded by a small multigene family in many species and have been shown to be differentially expressed in various tissues and developmental stages (Barry et al. 1996; Nakatsuka et al. 1998). ACO is a member of the 2oxoacid-dependent dioxygenase family of enzymes, and requires $\mathrm{Fe}^{2+}$ and ascorbate for optimal substrate conversion in vitro (Prescott 1993). It also requires $\mathrm{CO}_{2}$ as an essential cofactor (Dong et al. 1992). ACO is important in regulating ethylene synthesis; down-regulation of endogenous ACO expression in transgenic tomato reduced ethylene synthesis and hindered fruit ripening (Picton et al. 1993).

We are interested in the involvement of ethylene during development and growth of underground adventitious buds of leafy spurge, a perennial weed. Leafy spurge has numerous underground adventitious shoot buds that form on the crown and roots (commonly referred to as crown and root buds). These buds undergo well-defined phases of dormancy throughout the year (Anderson et al. 2005; Chao et al. 2006). In buds, dormancy is subdivided into three categories: (i) ecodormancy in which growth cessation is controlled by external environmental factors, (ii) paradormancy or correlative inhibition in which growth cessation is controlled by physiological factors external to the affected structure, and (iii) endodormacy or innate dormancy in which growth cessation is controlled by internal physiological factors (Lang et al. 1987). We found that in leafy spurge, paradormancy inhibits buds from developing into new shoots through signals generated from the actively growing aerial portion of the plant, namely auxin and sugars (Horvath 1998, 1999; Chao et al. 2006) and endodormancy is triggered by cold temperature and short photoperiods (Foley et al. 2009; Doğramac1 et al. 2013).

Although the role of ethylene in the development of bud dormancy is not well understood, this molecule appears to be important based on studies in various plant species. For example, Suttle (1998) showed that endogenous ethylene is critical for the development of adequate endodormancy in potato microtubers, where ethylene involvement is restricted to the initial phase of endodormancy induction. Similarly, in birch, ethylene signaling facilitates short dayinduced terminal bud formation and normal endodormancy development (Ruonala et al. 2006) based on observations made in ethylene-insensitive birch trees. In response to short days, these trees showed delayed endodormancy development, did not accumulate abscisic acid (ABA) in apical buds, and exhibited a bush-like appearance due to reduced apical dominance. These results suggest that ethylene signals interact with the ABA and auxin signaling pathways during endodormancy development (Ruonala et al. 2006).

While the above results argue for a role of ethylene in inducing endodormancy, other observations indicate that increases in ethylene synthesis may also lead to dormancy release and growth promotion. For example in grapes (Vitis vinifera), bud dormancy break can be induced with hydrogen cyanamide and heat shock (Dokoozlian et al. 1995). These treatments resulted in up-regulation of genes involved in ethylene signaling and biosynthesis, including ACC oxidase, which led to an increase in ethylene levels (Ophir et al. 2009). Furthermore, exogenous ethylene accelerated bud break in grapes, while this process was completely inhibited by the ethylene signaling inhibitor 2, 5-norbornadiene (Ophir et al. 2009). A role for ethylene in promoting dormancy release and/or promoting germination is also being increasingly recognized in seeds (Matilla and Matilla-Vázquez 2008; Bogatek and Gniazdowska 2012). In this organ, ethylene acts in conjunction with gibberellins as an antagonist of ABA facilitating endosperm weakening, and increasing embryo growth potential and radicle emergence (Matilla and Matilla-Vázquez 2008; Linkies and LeubnerMetzger 2012). Other well-known condition where an increase in ethylene is linked to growth promotion is submergence. Submerged tissues accumulate ethylene, which triggers various responses including shoot elongation (Fukao and Bailey-Serres 2008). 
This is an author-produced, peer-reviewed version of this article. The final, definitive version of this document can be found online at Planta, published by Springer-Verlag. Copyright restrictions may apply. DOI: 10.1007/s00425-013-1887-z.

Given that ethylene can promote growth at various stages of development and under different environmental conditions, we hypothesized that this hormone may also be involved in growth of leafy spurge buds, particularly after paradormancy release (growth induction) following removal of the aerial portion of the plant (decapitation). To explore this hypothesis, we examined ethylene production and the expression and activity of the ACC oxidase. A cDNA encoding a Euphorbia esula ACC oxidase (Ee-ACO) was cloned and the protein expressed from this clone was used to generate a polyclonal antibody against this enzyme. This study reports the expression, activity, and localization of the Ee-ACO enzyme during bud growth induction.

\section{Materials and methods}

\section{Plant materials}

Leafy spurge (Euphorbia esula L.) plants were started from shoot cuttings using plant material that originated from a wild population in North Dakota (Biotype 1984-ND-001) and have been maintained by clonal propagation in a greenhouse. Shoot cuttings from greenhouse-grown plants were placed in Sunshine I potting mix inside Ray Leach Cone-tainers and grown in a greenhouse under a $16: 8 \mathrm{hr}$ day:night photoperiod at $28 \pm 4^{\circ} \mathrm{C}$ for 3 to 4 months. Daylight was supplemented with $400 \mathrm{~W}$ high-pressure sodium lamps, which provided light fluencies of about $350 \mu \mathrm{mol} \mathrm{m}^{-2} \mathrm{~s}^{-1}$. Prior to the collection of adventitious buds, plants were left intact (control) or the entire plant above the base of the crown was excised; growth-induced buds were collected from these decapitated plants. The time of excision was scheduled so that the buds were harvested between 10 a.m. -12 p.m. to minimize circadian effects on gene expression.

Gene expression analysis using real-time $\mathrm{qPCR}$

Primer pairs were designed from an Ee-ACO gene obtained from a leafy spurge EST-database (Anderson et al. 2007). Primers (20-24 nucleotides) were designed using Lasergene (DNASTAR, Inc., Madison, WI, USA) sequence analysis software. Expression of this gene was examined using total RNA prepared from underground adventitious buds of growth-induced samples. Growth-induced bud samples were harvested from greenhouse-grown plants $0 \mathrm{~h}, 2 \mathrm{~h}, 4 \mathrm{~h}, 8$ h, $16 \mathrm{~h}, 1 \mathrm{~d}, 2 \mathrm{~d}, 3 \mathrm{~d}, 4 \mathrm{~d}$, and $5 \mathrm{~d}$ after shoot removal (decapitation). Two biological replicates, Rep 1 and Rep 2, of control and growth-induced bud samples were collected in April and June of 2006, respectively.

Total RNA was extracted from bud samples, quantified, and used to prepare cDNA template through reverse transcription (RT) reactions. The details of cDNA preparation and real-time PCR parameters were previously described (Chao 2008). Briefly, the standard comparative $\mathrm{C}_{\mathrm{T}}$ method $\left(\Delta \Delta \mathrm{C}_{\mathrm{T}}\right)$ was used to determine changes in target gene expression in test samples relative to a control sample. Fold difference in gene expression of test vs. control

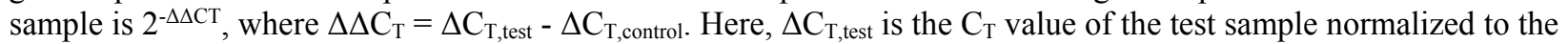
endogenous reference gene, and $\Delta \mathrm{C}_{\mathrm{T} \text {, control }}$ is the $\mathrm{C}_{\mathrm{T}}$ value of the control normalized to the same endogenous reference gene. A leafy spurge SAND family gene was used as a reference; this gene was verified to be stably expressed during growth (Chao et al. 2012). SYBR green chemistry was used to produce the fluorescent signal, and two technical replicates were used per sample for the RT-qPCR experiments. The $\mathrm{C}_{\mathrm{T}}$ value is the average of two technical replicates. Passive reference dye, 6-carboxyl-X-rhodamine (ROX), was used to normalize for non-PCR-related fluctuations in the fluorescent signal. Changes in gene expression are reported as $\log 2$ differences $\left(-\Delta \Delta \mathrm{C}_{\mathrm{T}}\right)$.

Antibody generation

A full-length Ee-ACO cDNA was cloned into two plasmid expression vectors, pMAL-c2X (New England Biolabs, Ipswich, MA, USA) and pGEX-4T-1 (Amersham Biosciences, Piscataway, NJ, USA) to generate fusion protein constructs using standard cloning methods. pMAL-c2X contains a malE gene which encodes maltose-binding protein (MBP) and pGEX-2T contains a glutathione S-transferase (GST) gene. Affinity-purified MBP-ACO was used as the antigen to generate a polyclonal ACO antibody. To isolate antibodies that specifically recognize ACO epitopes in MBP-ACO, a second ACO fusion protein (GST-ACO) was used to construct a column by coupling the affinity purified GST-ACO antigen to AminoLink coupling gel. Column construction and affinity purification of the Ee-ACO antibody were performed according to the manufacturer's instructions (Pierce Biotechnology, Rockford, IL, USA). 
This is an author-produced, peer-reviewed version of this article. The final, definitive version of this document can be found online at

Planta, published by Springer-Verlag. Copyright restrictions may apply. DOI: 10.1007/s00425-013-1887-z.

\section{Confirmation of Ee-ACO antibody}

Ee-ACO antibody was confirmed by immunoprecipitation. For immunoprecipitation, proteins were extracted from seedlings in a buffer containing $20 \mathrm{mM}$ Tris-HCl (pH 7.4), 5 mM EDTA, $5 \mathrm{mM}$ EGTA, $100 \mathrm{mM} \mathrm{NaCl}, 0.5 \%$ NP-40 (v/v), 1 mM DTT, 3\% protease inhibitor cocktail (v/v) (Sigma P9599), and 1\% PVPP (w/v). One ml of seedling protein extract was diluted to $1 \mathrm{mg} / \mathrm{ml}$ protein and incubated with $2 \mu \mathrm{g}$ of affinity purified antibody for $2 \mathrm{hr}$ at $4^{\circ} \mathrm{C}$. Subsequently, proteins were immunoprecipitated with $50 \mu \mathrm{l}$ bed volume of PBS-washed protein G-Sepharose 4B (Amersham Biosciences, Piscataway, NJ, USA) and washed three times with PBS.

Determination of protein levels

Protein levels were determined by immunoblot analysis. Protein samples were phenol extracted as described by Wang et al. (1992) with some modification in solubilization buffer. Briefly, one gram of material was ground in liquid nitrogen and extracted in $10 \mathrm{ml}$ of extraction buffer consisting of $0.7 \mathrm{M}$ sucrose, $0.5 \mathrm{M}$ Tris base, $30 \mathrm{mM} \mathrm{HCl}, 50 \mathrm{mM}$ EDTA, $0.1 \mathrm{M} \mathrm{KCl}, 2 \% \beta$-mercaptoethanol, and $2 \mathrm{mM}$ PMSF. The extract was mixed with an equal volume of watersaturated phenol. After stirring at $4{ }^{\circ} \mathrm{C}$ for $30 \mathrm{~min}$, the phases were separated by centrifugation at $15,000 \mathrm{x} g$ for 10 min and the phenol phase was extracted. Protein partitioning into the phenol phase were precipitated with five volumes of $0.1 \mathrm{M}$ ammonium acetate in methanol at $-20^{\circ} \mathrm{C}$ overnight. The precipitate was washed three times with $0.1 \mathrm{M}$ ammonium acetate in methanol and once with $100 \%$ acetone. The pellet was dried and resuspended in solubilization buffer consisting of $8 \mathrm{M}$ urea, $2 \%(\mathrm{w} / \mathrm{v})$ CHAPS, $25 \mathrm{mM}$ dithiothreitol, $0.2 \%$ BIO-LYTE 1-10, and a trace amount of bromophenol blue. SDS-PAGE was carried out according to the method of Laemmli (1970) using a $10 \%$ polyacrylamide resolving gel and a $4 \%$ stacking gel. Mini gels were electrophoresed in the running buffer $(25 \mathrm{mM}$ Tris base, $192 \mathrm{mM}$ glycine, $0.1 \%$ SDS) at 10-15 volts until the dye front reached the bottom of the gel. Immunoblot analysis was performed according to the standard procedures using Ee-ACO antibody $(0.24 \mu \mathrm{g} / \mu \mathrm{l})$ at a 1:1250 dilution. Secondary antibodies were anti-rabbit IgG-conjugated with alkaline phosphatase (Sigma, A0418) at 1:10,000 dilutions. The blots were developed using a SIGMA FAST ${ }^{\mathrm{TM}}$ BCIP/NBT kit according to manufacturer's instructions (Sigma-Aldrich, St. Louis, MO, USA). The intensities of the protein bands were measured using a Fluor-S MultiImager and Quantity One 4.0 software (BioRad, Hercules, CA, USA).

\section{Ethylene measurements}

Four-month old greenhouse-grown leafy spurge plants were left intact or excised just above the base of the crown (cut). For each of these two treatments, buds were removed from five plants at six time periods $(2 \mathrm{~h}, 6 \mathrm{~h}, 24 \mathrm{~h}, 48 \mathrm{~h}$, $72 \mathrm{~h}$, and $96 \mathrm{~h}$ ). For each treatment and sampling period, buds were incubated in either10 mM MES (-ACC) or 1.0 $\mathrm{mM}$ ACC $+10 \mathrm{mM}$ MES $(+\mathrm{ACC})$ for one hour in the dark at $20^{\circ} \mathrm{C}$. The buds were then removed from their respective buffer and blotted dry. Per treatment and sampling period, fifteen uniform sized buds were selected and equally distributed among three $10 \mathrm{ml}$ syringes. The syringes were then set to a $5 \mathrm{ml}$ headspace volume and sealed with a stopper. After two-hour incubation in the dark $\left(20^{\circ} \mathrm{C}\right)$, one $\mathrm{ml}$ of gas sample was extracted from each syringe. Ethylene was determined by gas chromatography on a Varian 3400 gas chromatograph, using a 45-cm-long alumina (60-80 mesh) column operating at $80^{\circ} \mathrm{C}$, with a nitrogen carrier gas flow rate of $30 \mathrm{ml} \mathrm{min}^{-1}$, and injector/detector temperatures of $150^{\circ} \mathrm{C} / 250^{\circ} \mathrm{C}$, respectively (Suttle 2003). A duplicate study was repeated the following week. The data of these two studies were combined for the analysis because no significant differences were observed between them. The effects of the various treatments on ethylene synthesis were evaluated using the MIXED procedure model in SAS 9.3 (SAS Institute Inc., Cary, NC, USA) for a completely randomized design. Fixed factors in the analysis were time of bud removal $(2,6,24,48,72$, or $96 \mathrm{~h})$, excision treatment (intact or cut), ACC treatment (-/+), and the interactions between these factors. Prior to statistical analyses, the ethylene data was Box-Cox transformed to create a normal distribution, which was not present in the original data based on the Shapiro-Wilk's test. Significant differences among treatments were determined using Tukey-Kramer least square means test at $P<0.05$.

\section{ACO Assay}

ACO activity was determined using protein extracts obtained from crown buds of 4.5- or 4-month old greenhousegrown leafy spurge plants (designated as Rep 1 and Rep 2, respectively). One gram of crown buds harvested from intact $(0 \mathrm{~d})$ and growth induced plants $(3 \mathrm{~d}$ and $4 \mathrm{~d})$ was ground in liquid nitrogen and extracted in $10 \mathrm{ml}$ of ACO protein extraction buffer $(50 \mathrm{mM}$ Tris $\mathrm{pH} 7.4,30 \mathrm{mM}$ Na ascorbate, $2 \mathrm{mM}$ DTT, 1\% PVPP, 3\% protease inhibitor cocktail, and $20 \% \mathrm{NP}-40$ ). The extract was centrifuged at $15,000 \mathrm{x} \mathrm{g}$ for $20 \mathrm{~min}$ at $4{ }^{\circ} \mathrm{C}$ and the supernatant filtered 
through a $0.8 \mu \mathrm{M}$ syringe filter. The protein concentration of the filtrates was determined $(1 \mu \mathrm{g} / \mu \mathrm{L}$ for Rep 1 and Rep 2 ), and the filtrates were used to measure ACO activity. The reaction mixture contained $50 \mathrm{mM}$ Tris $\mathrm{pH} 7.5,30 \mathrm{mM}$ Na ascorbate, $2 \mathrm{mM}$ DTT, $50 \mathrm{uM} \mathrm{FeSO} 4,1 \mathrm{mM} \mathrm{ACC}, 30 \mathrm{mM} \mathrm{NaHCO}_{3}$, and 10\% (v/v) glycerol in a sealed $15-\mathrm{ml}$ test tube. The reaction was initiated by the addition of $100 \mu \mathrm{L}$ of the filtrate into the reaction mixture. After incubation for $45 \mathrm{~min}$ at $30^{\circ} \mathrm{C}$ in a shaker, a $1-\mathrm{ml}$ gas sample was withdrawn from the tube air space and used for ethylene determination (Dong et al. 1992). A "45 min" incubation time was selected based on preliminary tests that showed linearity of Ee-ACO activity within the first $60 \mathrm{~min}$ of incubation (data not shown). ACO activity was measured in control extracts (without antibody) and on extracts that have been incubated with 5, and $10 \mu \mathrm{g}$ of the Ee-ACO antibody to remove Ee-ACO protein. After incubation, antibody-bound Ee-ACO was immunoprecipitated onto Protein G sepharose 4 Fast Flow (GE Healthcare). After centrifugation at $4^{\circ} \mathrm{C}$ and $6,000 \mathrm{rpm}$ for $4 \mathrm{~min}$, the supernatant was used to measure ACO activity. In addition to the above measurements of ACO activity in protein extracts, we also determined the activity of the GST-ACO fusion protein to ascertain that the Ee-ACO is functional and responsible for ethylene synthesis in vivo. For this purpose, the reaction conditions and ethylene determination procedures were the same as those described above. Statistical differences on ACO activity after growth induction or following immunoprecipitation were evaluated by one-way ANOVA in SAS 9.3. Data were not transformed prior to statistical analyses because the data satisfied the assumptions of homoscedasticity and normality based on the Bartlett's and Shapiro-Wilk's test, respectively.

Immunolocalization

For immunolocalization studies, underground adventitious buds were fixed in $4 \%(\mathrm{w} / \mathrm{v})$ paraformaldehyde in $50 \mathrm{mM}$ Pipes (pH 6.9) containing $5 \mathrm{mM} \mathrm{MgSO}_{4}$ and $5 \mathrm{mM}$ EGTA and embedded in 4:1 (v/v) butyl methacrylate to methyl methacrylate (Polysciences, Inc., Warrington, PA, USA) as described by Baskin et al. (1992). Samples were sectioned at a thickness of $3 \mu \mathrm{m}$ and affixed to slides coated with 3-aminopropyltriethoxysilane. After removal of the methacrylate, sections were treated with a blocking buffer ( $\mathrm{pH}$ 7.4) consisting of $100 \mathrm{mM} \mathrm{K}$-phosphate, $138 \mathrm{mM}$ $\mathrm{NaCl}, 2.7 \mathrm{mM} \mathrm{KCl}, 0.5 \%$ Tween 20 (Pierce Biotechnology) and 10\% horse serum (Sigma). The sections were then incubated for $2 \mathrm{~h}$ with a 1:200 dilution of the Ee-ACO antibody in blocking buffer. After rinsing with blocking buffer, bound primary antibody was detected using goat anti-rabbit antibody conjugated to Alexa Fluor 488 (Molecular Probe, Eugene, OR). To ascertain the specificity of the antibodies to the sections, we conducted two controls. Some sections were incubated with secondary antibody only, while others were incubated with primary antibody preabsorbed with the ACO protein at a molar ratio of ACO protein to antibody of 50 to 1. After immunolabeling, propidium iodide was used for nuclear counter-staining.

\section{Results}

Increase in ethylene levels required the addition of $\mathrm{ACO}$

To examine the effect of growth induction on ethylene synthesis, crown buds were collected from non-growth (intact) and growth-induced (cut) plants and incubated with or without $1 \mathrm{mM} \mathrm{ACC}$. The statistical analysis showed significant interactions between the factors considered $(p<0.001)$; which is reflected on the different effects of ACC on intact and cut buds, and overtime. Without ACC, ethylene levels did not increase in either intact or cut buds (Fig 1). In contrast, ACC addition led to an increase in ethylene synthesis, but only in buds harvested $96 \mathrm{~h}$ after growth induction (Fig. 1). These buds showed higher ethylene production than those collected earlier. Moreover, no increase in ethylene levels was observed for ACC-incubated buds that were collected from intact plants (intact, + ACC), suggesting that the levels of the ACC oxidase (ACO) increased in growing buds.

\section{Ee-ACO transcript levels increased after growth induction}

To test if the increase in ACC-dependent ethylene production correlates with an increase in ACO transcripts during bud growth, a cDNA clone (Ee-ACO) was obtained from our leafy spurge EST-database (Anderson et al. 2007). The deduced amino acid sequence of Ee-ACO shared significant sequence identity with ACO from other plant species. For example, Ee-ACO shares $88 \%$ sequence identity with two Euphorbiaceae species, the para rubber tree (Hevea brasiliensis, CAN85571) and cassava (Manihot esculenta, ABK58140), and $88 \%$ and $79 \%$ sequence identity with ACOs from Populus trichocarpa (Pt EEE98802) and Arabidopsis thaliana (At1G05010), respectively (Fig. 2). Based 


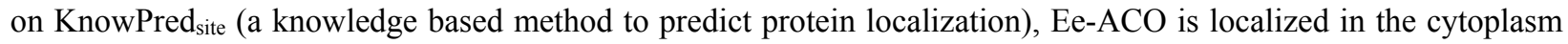
and nucleus with a confidence score of 30.01 and 28.57, respectively. The expression of Ee-ACO transcript was examined in two sets of growth-induced (Rep 1 and Rep 2) crown bud samples using qRT-PCR (Fig. 3). The transcript of an Ee-ACO was found to increase up to 3-folds after growth induction following decapitation.

To ascertain that this Ee-ACO encodes an endogenous leafy spurge ACO responsible for ethylene synthesis, a GST and Ee-ACO fusion protein (GST-ACO) was generated, affinity purified, and its ACO activity determined. Our results showed that the GST-ACO protein produced as much as $460 \mathrm{~nL}$ ethylene $\mathrm{hr}^{-1} \mathrm{~g}^{-1}$ protein (data not shown).

Ee-ACO protein and activity levels increased after growth induction

To further examine the expression and activity of Ee-ACO, a polyclonal antibody was generated from a MBP-EeACO fusion protein and used for various studies including immunoblot analysis, activity assays, and immunolocalization. Immunoblot analyses of crude protein samples from seedlings showed that the Ee-ACO antibody identified a major protein with a molecular weight of $36-\mathrm{kD}$ (Fig. $4 \mathrm{a}, 1^{\text {st }}$ lane). Furthermore, the Ee-ACO antibody immunoprecipated the $36 \mathrm{kD}$ protein from a crude protein extract from seedlings ( $3^{\text {rd }}$ lane). However, this procedure did not precipitate all Ee-ACO since the $36-\mathrm{kD}$ protein was also present in the supernatant after immunoprecipitation ( $2^{\text {nd }}$ lane).

Ee-ACO abundance was investigated in crown buds before and after growth induction and in other plant organs and tissues. The $36-\mathrm{kD}$ protein was identified in all plant parts examined. Ee-ACO was highly expressed in leaves, moderately expressed in crown buds, stems and meristems, and weakly expressed in roots and flowers (Fig. 4b); the difference in Ee-ACO abundance among these tissues could be as high as 5-fold. Ee-ACO was present in paradormant crown buds, but the levels of this protein progressively increased during the first five days after growth induction (Fig. $4 \mathrm{c})$. This result correlated well with the expression of Ee-ACO transcript, which showed moderate increase after growth induction.

In addition to the increase in Ee-ACO expression, growth induction caused a rise in apparent ACO activity. Within the first four days after decapitation, we observed 2.5 and 4-folds increases in vitro ACO activity in crude protein extracts from 4.5- and 4-month-old (Rep 1 and Rep 2) crown buds, respectively (Fig. 5a). Moreover, an enzyme partially responsible for this activity was removed by immunoprecipitation using 5 and $10 \mu \mathrm{g}$ of the Ee-ACO antibody (Fig. 5b). These procedures resulted in $40 \%$ reduction in ACO activity with respect to the non-immunoprecipitated control (Fig. 5b).

Ee-ACO is localized in the nucleus and cytoplasm of growing buds

To determine Ee-ACO protein expression at the cellular and subcellular levels, sections of control and 4 day growthinduced crown buds were incubated with the Ee-ACO antibody. No clear differences in antibody labeling were observed between these two time points; thus, only the results of 4-day old crown buds are shown (Fig. 6). The green fluorescence indicates binding of the Ee-ACO antibody to the sections (f-i) and the red fluorescence reveals staining of the nuclei with propidium iodide (c, f-i). Preincubation of the Ee-ACO antibody with the MBP-ACO completely inhibited binding of the antibody to the sections (a-c). Strong labeling of Ee-ACO was shown in the nucleus and cytoplasm of young cells at the shoot apical meristem and leaf primordia (d-i). Higher magnification showed an exception to this pattern; labeling of Ee-ACO was negligible in cells undergoing mitosis (h and i). These observations suggest that ethylene is synthesized in cells of growing buds, but only during certain stages of the cell cycle. 


\section{Discussion}

Decapitation increases the expression of ACC oxidase

Our results showed that decapitation of leafy spurge is associated with an increase in the ACO transcript, ACO protein, and ACO activity. Increases in the levels of the ACO transcript occurred within the first day after decapitation, while increases in ACO protein amount and activity appeared to reach a maximum four days after decapitation. The increase in ACO activity was observed in both protein extracts and in bud feeding experiments. However, the time course of these changes was different. Protein extracts showed a 2 to 3 fold increase in ACO activity $3 \mathrm{~d}$ after decapitation. In contrast, the increase in ethylene synthesis was delayed to day $4(96 \mathrm{~h})$ after decapitation in buds and only occurred if buds were supplemented with ACC.

The need for ACC addition to increase ethylene synthesis suggests, that $4 \mathrm{~d}$ after decapitation, bud production of this hormone was not limited by ACO but rather ACC availability. The conversion of AdoMet to ACC by ACC synthase is often a rate-limiting step in ethylene synthesis (Argueso et al. 2007). Perhaps, a similar situation occurs at early stages of bud sprouting in leafy spurge. However, further work is needed to determine whether the ACC limitation was present in the buds prior to their excision from the plants or developed during the measurement procedure, which involved bud excision. A decrease in ACC synthase activity following excision seems unlikely because this event requires some wounding that tends to increase ACC synthase expression (Boller and Kende 1980; Argueso et al. 2007). Nevertheless, ACC may decrease if the growing bud depends on imports from the roots to maintain the Yang cycle.

While ACC promoted ethylene synthesis in $4 \mathrm{~d}$ buds, it did not have such effect on $3 \mathrm{~d}$ buds (Fig. 1). This was somewhat unexpected because protein extracts from growth-induced $3 \mathrm{~d}$ buds showed levels of ACO expression and activity somewhat similar to $4 \mathrm{~d}$ buds and clearly higher than the $0 \mathrm{~d}$ controls (cf. Fig. $4 \mathrm{c}$ and $5 \mathrm{~b}$ ). In addition to ACC, ACO requires $\mathrm{O}_{2}$ as a substrate, ascorbate as co-substrate, and $\mathrm{Fe}^{2+}$ and $\mathrm{CO}_{2}$ as cofactors (Dong et al. 1992). Inadequate levels of any of these molecules could have limited ACO activity despite the increase in ACO expression (Yip et al. 1988; Sanders and de Wild 2003; Zechmann 2011). At least in excised buds, the results suggest sequential changes in the factors limiting ACO activity after growth induction, with perhaps cofactors limiting at day 3 and ACC at day 4 .

Although the ACO protein and ACO activity increased after decapitation, the magnitude of this increase was different. In general, the increase in ACO activity was higher than the increase in ACO protein accumulation. This suggests that some type of post-translational modification could occur to this enzyme after growth induction. Alternatively, EeACO activity was only a fraction of the total ACO activity in these buds and, like Ee-ACO, related ACOs might increase after decapitation. The immunoprecipitation experiment using 5 and $10 \mu \mathrm{g}$ of the Ee-ACO antibody supports this notion. Immunoprecipitation resulted in $40 \%$ reduction in the total ACO activity (Fig. 5b). This suggests that $60 \%$ of the total ACO activity was attributed to related ACOs that were not immunoprecipitated by the Ee-ACO antibody. Still, there was a possibility that a fraction of Ee-ACO could not be precipitated by Ee-ACO antibody, and thus $60 \%$ of the total ACO activity was attributed to both non-precipitated Ee-ACO and related ACOs; this would underestimate the total Ee-ACO activity. Thus, our work showed that Ee-ACO is one of the major enzymes responsible for ethylene production in buds, but most likely not the only one.

There were also differences in the time course and magnitude of ACO activity between the two biological replicates. In Rep 1, similar and high levels of activity were measured in days 3 and 4 after decapitation. In contrast in Rep 2, there was a significant increase in activity between days 3 and 4 . Moreover, the magnitude of ACO activity was markedly different between the two replicates. The highest ACO activity was $21.2 \mathrm{~nL} \mathrm{~g}^{-1} \mathrm{FW} \mathrm{hr}^{-1}$ for Rep 1, but only $6.5 \mathrm{~nL} \mathrm{~g}^{-1} \mathrm{FW} \mathrm{hr}{ }^{-1}$ for Rep 2. On the other hand, Rep 2 showed a higher fold difference with respect to the $0 \mathrm{~d}$ control than Rep 1, 4 and 2.5 folds, respectively. These variations in ACO activity could be due to differences in bud age since samples for Rep 1 and Rep 2 were from 4.5 and 4 month-old plants, respectively. Also, Rep 1 and Rep 2 were harvested at distinct times of the year. This may have resulted in differences in ACO activity, even though the plants were grown under similar greenhouse conditions. 
Does Ee-ACO play a regulatory role in ethylene production and growth?

The rise in ACO activity that occurs as leafy spurge buds exit paradormancy indicates an increase in the bud capacity for ethylene synthesis. This increased capacity is likely to eventually enhance ethylene synthesis. However, the moment at which the increase in ethylene synthesis takes place is not clear from our measurements. Perhaps, the rise in ACO expression is in preparation for increases in ethylene synthesis that occur 5 or more days after decapitation. At this time the buds undergo a very rapid elongation to become young shoots. Accumulation of ACO transcripts and increases in ethylene synthesis has been correlated with growth promotion in a variety of situations and a similar phenomenon may occur in sprouting leafy spurge buds. For example, in deepwater rice accumulation of ethylene as result of physical entrapment and increased biosynthesis leads to rapid rates of shoot elongation and carbohydrate metabolism (Fukao and Bailey-Serres 2008; Iwamoto et al. 2010). Similarly, Pierik et al. (2004) found that low red to far-red ratios enhanced ethylene production and stimulated shade avoidance response in wild-type tobacco, while much reduced responses were observed in ethylene-insensitive plants. A growth promoting effect of ethylene has also been observed during seed germination. In chick-pea (Cicer arietinum L.) seeds; ethylene levels were elevated in the embryonic axis and reached its highest value when radicle emergence occurred. In addition, radicle emergence was accompanied by elevated levels of ACC, ACO transcript, and ACO activity (Gómez-Jiménez et al. 2001). Our previous studies on seed germination of leafy spurge using microarrays also indicate a role of ethylene signaling in radicle emergence. In these studies, the principal small molecule hub of over-represented genes shifted from gibberellic acid just prior to germination to ethylene at germination (Chao et al. 2011). Based on all of these findings, the ethylene signaling pathway might be an important conduit for growth. However, studies on bud outgrowth following treatments that limit ethylene production or signaling would be needed to ascertain a direct requirement for ethylene in bud outgrowth.

Ethylene may be synthesized in the cytoplasm and nucleus of young, non-dividing cells

Immunolocalization analysis showed that Ee-ACO is located in both the cytoplasm and nucleus of young cells at the shoot apical meristem and leaf primordia (Fig. 6). In addition, a confidence score of $\sim 30$ was obtained for both cytoplasm and nucleus localization from the predicted amino acid sequences of Ee-ACO, providing additional evidence that Ee-ACO is localized in these two cellular compartments. These results were similar to the findings of Hudgins and Franceschi (2004) in Douglas fir (Pseudotsuga menziesii), where transmission electron microscopy showed clear labeling of the nucleus. In other plant species, ACOs have been observed in the cell wall/apoplast (Rombaldi et al. 1994; Gómez-Jiménez et al. 2001) and the cytosol (Chung et al. 2002). Localization in the cell wall is particularly intriguing because ACO does not contain a typical N-terminal sequence for transport into the endoplasmic reticulum (Chung et al. 2002). Ethylene in the cytoplasm has been postulated to play important roles for ethylene signal transduction and the MAPK pathway (Hahn and Harter 2009; Zhao and Guo 2011). Very little is known about the role that ACO may play in the nucleus. Nuclear ACO may have a similar function as in the cytoplasm, but this remains to be tested. Interestingly, no (or negligible) ACO was identified in young cells undergoing mitosis indicating that ACO synthesis and turnover were under complex and tight control at the cellular and sub-cellular levels. Unlike the immunoblot analyses (Fig. 4c), no discrete differences in Ee-ACO localization were observed between control buds (data not shown) and 4-day growth induced buds. This discrepancy is not surprising because immunoblot analysis is more sensitivity than immunolocalization in detecting differences in protein levels, and our results clearly indicate that $\mathrm{ACO}$ is present at all time points.

In summary, our results revealed that the release from paradormancy in leafy spurge leads to an increase in ACO expression and a rise in ACO activity in bud protein extracts. This rise in activity was not limited to the Ee-ACO transcript reported, but also seems to reflect the contribution of other ACO enzymes. In the buds, the increase in ACO expression was not accompanied by equivalent increases in ethylene synthesis. This indicates that regulation of ACO activity in situ may be limited by other factors such as the levels of substrates and cofactors for this enzyme. As judged by the differential response of buds to the addition of ACC, changes in factors limiting ACO activity appeared to occur between 3 and $4 \mathrm{~d}$ following decapitation. The discrepancies between in vitro and in situ ACO activities suggest a complex regulation of ethylene synthesis following growth induction of leafy spurge.

\section{Acknowledgments}

The authors acknowledge Wayne Sargent, USDA-ARS, Fargo, ND, for his technical assistance. 


\section{References}

Anderson JV, Gesch RW, Jia Y, Chao WS, Horvath DP (2005) Seasonal shifts in dormancy status, carbohydrate metabolism, and related gene expression in crown buds of leafy spurge. Plant Cell Environ 28:1567-1578

Anderson JV, Horvath DP, Chao WS, Foley ME, Hernandez AG, Thimmapuram J, Liu L, Gong GL, Band M, Kim R, Mikel MA (2007) Characterization of an EST database for the perennial weed leafy spurge: an important resource for weed biology research. Weed Sci 55:193-203

Argueso CT, Hansen M, Kieber JJ (2007) Regulation of ethylene biosynthesis. J Plant Growth Regul 26:92-105

Barry CS, Blume B, Bouzayen M, Cooper W, Hamilton AJ, Grierson D (1996) Differential expression of the 1aminocyclopropane-1-carboxylate oxidase gene family of tomato. Plant J 9:525-535

Baskin TI, Busby CH, Fowke LC, Sammut M, Gubler F (1992) Improvements in immunostaining samples embedded in methacrylate: Localization of microtubules and other antigens throughout developing organs in plants of diverse taxa. Planta 187:405-413

Bleecker AB, Kende H (2000) Ethylene: a gaseous signal molecule in plants. Annu Rev Cell Dev Biol 16:1-18

Bogatek R, Gniazdowska A (2012) Ethylene in seed development, dormancy and germination. Annu Plant Rev 44:189-218

Boller T, Kende H (1980) Regulation of wound ethylene synthesis in plants. Nature 286:259-260

Bradford KJ (2008) Shang Fa Yang: Pioneer in plant ethylene biochemistry. Plant Sci 175:2-7

Chao WS (2008) Real-time PCR as a tool to study weed biology. Weed Sci 56:290-296

Chao WS, Doğramaci M, Foley ME, Horvath DP, Anderson JV (2012) Selection and validation of endogenous reference genes for qRT-PCR analysis in leafy spurge (Euphorbia esula). PLoS ONE 7, e42839. doi:10.1371/journal.pone.0042839.

Chao WS, Foley ME, Doğramacı M, Anderson JV, Horvath DP (2011) Alternating temperature breaks dormancy in leafy spurge seeds and impacts signaling networks associated with HY5. Funct Integr Genomics 11:637-649

Chao WS, Serpe MD, Anderson JV, Gesch RW, Horvath DP (2006) Sugars, hormones, and environment affect the dormancy status in underground adventitious buds of leafy spurge (Euphorbia esula L.). Weed Sci 54:59-68

Chen YF, Etheridge N, Schaller GE (2005) Ethylene signal transduction. Ann Bot 95:901-915

Chung MC, Chou SJ, Kuang LY, Charng YY, Yang SF (2002) Subcellular localization of 1-aminocyclopropane-1carboxylic acid oxidase in apple fruit. Plant Cell Physiol 43:549-554

Doğramacı M, Foley ME, Chao WS, Christoffers MJ, Anderson, JV (2013) Induction of endodormancy in crown buds of leafy spurge (Euphorbia esula L.) implicates a role for ethylene and cross-talk between photoperiod and temperature. Plant Mol Biol (in press), DOI 10.1007/s11103-013-0026-3

Dokoozlian NZ, Williams LE, Neja RA (1995) Chilling exposure and hydrogen cyanamide interact in breaking dormancy of grape buds. HortScience 30:1244-1247

Dong JG, Fernandez-Maculet JC, Yang SF (1992) Purification and characterization of 1-aminocyclopropane-1carboxylate oxidase from apple fruit. Proc Natl Acad Sci USA 89:9789-9793

Dorling SJ, McManus MT (2012) The fate of ACC in higher plants. Annu Plant Rev 44:83-115

Foley ME, Anderson JV, Horvath DP (2009) The effects of temperature, photoperiod, and vernalization on regrowth and flowering competence in Euphorbia esula (Euphorbiaceae) crown buds. Botany 87:986-992

Fukao T, Bailey-Serres J (2008) Ethylene-A key regulator of submergence responses in rice. Plant Sci 175:43-51

Gómez-Jiménez MD, García-Olivares E, Matilla AJ (2001) 1-aminocyclopropane-1-carboxylate oxidase from embryonic axes of germinating chick-pea (Cicer arietinum L.) seeds: cellular immunolocalization and alterations in its expression by indole-3-acetic acid, abscisic acid and spermine. Seed Sci Res 11:243-253

Hahn A, Harter K (2009) Mitogen-activated protein kinase cascades and ethylene: signaling, biosynthesis, or both? Plant Physiol 149:1207-1210

Horvath DP (1998) The role of specific plant organs and polar auxin transport in correlative inhibition of leafy spurge (Euphorbia esula) root buds. Can J Bot 76:1227-1231

Horvath DP (1999) Role of mature leaves in inhibition of root bud growth in Euphorbia esula L. Weed Sci 47:544550

Hudgins JW, Franceschi VR (2004) Methyl jasmonate-induced ethylene production is responsible for conifer phloem defense responses and reprogramming of stem cambial zone for traumatic resin duct formation. Plant Physiol 135:2134-2149

Iwamoto M, Baba-Kasai A, Kiyota S, Hara N, Takano M (2010) ACO1, a gene for aminocyclopropane-1carboxylate oxidase: effects on internode elongation at the heading stage in rice. Plant Cell Environ 33:805815 
Kendrick MD, Chang C (2008) Ethylene signaling: new levels of complexity and regulation. Curr Opin Plant Biol $11: 479-485$

Laemmli UK (1970) Cleavage of structural proteins during the assembly of the head of bacteriophage T4. Nature 227:680-685

Lang GA, Early JD, Martin GC, Darnell RL (1987) Endo-, para-, and ecodormancy: physiological terminology and classification for dormancy research. HortScience 22:371-377

Linkies A, Leubner-Metzger G (2012) Beyond gibberellins and abscisic acid: how ethylene and jasmonates control seed germination. Plant Cell Rep 31:253-270

Matilla AJ, Matilla-Vazquez MA (2008) Involvement of ethylene in seed physiology. Plant Sci 175:87-97

Nakatsuka A, Murachi S, Okunishi H, Shiomi S, Nakano R, Kubo Y, Inaba A (1998) Differential expression and internal feedback regulation of 1-aminocyclopropane-1-carboxylate synthase, of 1-aminocyclopropane-1carboxylateoxidase, and ethylene receptor genes in tomato fruit during development and ripening. Plant Physiol 118:1295-1305

Ophir R, Pang X, Halaly T, Venkateswari J, Lavee S, Galbraith D, Or E (2009) Gene-expression profiling of grape bud response to two alternative dormancy-release stimuli expose possible links between impaired mitochondrial activity, hypoxia, ethylene-ABA interplay and cell enlargement. Plant Mol Biol 71:403-423

Picton S, Barton SL, Bouzayen M, Hamilton AJ, Grierson D (1993) Altered fruit ripening and leaf senescence in tomatoes expressing an antisense ethylene-forming enzyme transgene. Plant J 3:469-481

Pierik R, Cuppens ML, Voesenek LA, Visser EJ (2004) Interactions between ethylene and gibberellins in phytochrome-mediated shade avoidance responses in tobacco. Plant Physiol 136:2928-2936

Pierik R, Tholen D, Poorter H, Visser EJW and Voesenek LACJ (2006) The Janus face of ethylene: growth inhibition and stimulation. Trends Plant Sci 11:176-183

Prescott AG (1993) A dilemma of dioxygenases (or where biochemistry and molecular biology fail to meet). J Exp Bot 44: 849-861

Rombaldi C, Lelièvre J-M, Latché A, Petitprez M, Bouzayen M, Pech JC (1994) Immunocytolocalization of 1aminocyclopropane-1-carboxylic acid oxidase in tomato and apple fruit. Planta 192:453-460

Ruonala R, Rinne PLH, Baghour M, Moritz T, Tuominen H, Kangasjärvi J (2006) Transitions in the functioning of the shoot apical meristem in birch (Betula pendula) involve ethylene. Plant J 46:628-640

Sanders MG, de Wild HPJ (2003) The relation between in vivo ethylene production and oxygen partial pressure. Postharvest Biol Technol 30:143-151

Stepanova AN, Alonso JM (2009) Ethylene signaling and response: where different regulatory modules meet. Curr Opin Plant Biol 12:548-555

Suttle JC (1998) Involvement of ethylene in potato microtuber dormancy. Plant Physiol 118:843-848

Suttle JC (2003) Auxin-induced sprout growth inhibition: role of endogenous ethylene. Am J Potato Res 80:303-309

Wang CS, Walling LL, Eckard KJ, Lord EM (1992) Patterns of protein accumulation in developing anthers of Lilium Longiflorum correlate with histological events. Am J Bot 79:118-127

Yip WK, Jiao XZ, Yang SF (1988) Dependence of in vivo ethylene production on 1-aminocyclopropane-1carboxylic acid content and oxygen concentrations. Plant Physiol 88:553-558

Zechmann B (2011) Subcellular distribution of ascorbate in plants. Plant Signal Behav 6:360-363

Zhao Q and Guo H-W (2011) Paradigms and paradox in the ethylene signaling pathway and interaction network. Mol Plant 4:626-634 
This is an author-produced, peer-reviewed version of this article. The final, definitive version of this document can be found online at Planta, published by Springer-Verlag. Copyright restrictions may apply. DOI: 10.1007/s00425-013-1887-z.

\section{Legends}

Fig. 1 Ethylene production after growth induction. Crown buds of non-growth-induced (intact) and growth-induced (cut) plants were incubated with (+ACC) or without (-ACC) $1 \mathrm{mM} \mathrm{ACC}$. Two sets of time point samples $(2 \mathrm{~h}, 6 \mathrm{~h}$, $24 \mathrm{~h}, 48 \mathrm{~h}, 72 \mathrm{~h}$, and $96 \mathrm{~h})$ were used. Vertical bars represent the mean ( $\pm \mathrm{SE})$. The results are combined data of two experiments. Means not labeled by the same letter are significantly different $(p<0.05)$

Fig. 2 Deduced amino acid sequence comparison among ACO proteins. The deduced ACO sequence of leafy spurge (Ee-ACO) was compared with poplar (Pt EEE98802), para rubber tree (CAN85571), cassava (ABK58140), and Arabidopsis (At1G05010)

Fig. 3 Transcript levels for Ee-ACO. The expression of Ee-ACO transcript was examined using real-time PCR after growth induction. Two sets of growth-induced (Rep 1 and Rep 2) crown bud samples were used. The comparative $\mathrm{C}_{\mathrm{T}}$ method was used to determine changes in transcript expression levels in test samples relative to a control sample. The control for growth-induced samples was $0 \mathrm{~h}$ buds $(0 \mathrm{~h})$, and a leafy spurge SAND family gene was used as a reference for data normalization. Differences are expressed as $\log 2$ fold values (which are equivalent to $-\Delta \Delta \mathrm{C}_{\mathrm{T}}$ values); symbols represent the mean ( $\pm \mathrm{SE})$.

Fig. 4 Immunoprecipitation and protein expression analysis of Ee-ACO. a The Ee-ACO antibody was used to perform immunoprecipitation with Tris-buffer extracted leafy spurge seedling protein. b-c Leafy spurge total proteins were phenol-extracted from various tissues (b) as well as growth-induced (c) bud samples. These samples were fractionated by SDS-PAGE (10 $\mu \mathrm{g}$ per lane), blotted onto a membrane, and incubated with the Ee-ACO antibody. Bud samples were harvested from intact control plants ( 0 ) or at various time points ( 1 through 5 days) after growth induction. The 2006 and 2007 sample sets were used as biological replicates. The intensities of Ee$\mathrm{ACO}$ bands were quantified in $\mathbf{b}$ and $\mathbf{c}$. Relative intensities were determined by setting the strongest band from each blot equal to 100

Fig. 5 ACO activities after growth induction. a ACO activities were determined after growth induction using 4.5(Rep 1) or 4-month old (Rep 2) crown buds. Time points after growth induction are indicated in days (d). The y-axis value at the left side of the chart (0-25) represents the ethylene levels of Rep 1, and the y-axis value at the right side of the chart (0-8) represents the ethylene levels of Rep 2. b ACO activities in crown buds of leafy spurge $4 \mathrm{~d}$ after growth induction, comparison between non-treated protein extracts (control) and treated protein extracts in which a fraction of the endogenous Ee-ACO was removed by immunoprecipitation using 5 and $10 \mu \mathrm{g}$ of the Ee-ACO antibody. The activities presented are the average values of three technical replicates and vertical bars represent the mean $( \pm \mathrm{SD})$. Means not labeled by the same letter are significantly different $(p<0.05)$. In a, the mean comparison was made separately for each biological replication

Fig. 6 Immunolocalization of Ee-ACO protein in crown buds of leafy spurge. Sections were prepared from 4 dayold crown buds. Green label indicates the interaction of Ee-ACO antibody and its antigen, and red label shows the nuclei that were stained with propidium iodide (PI). a Ee-ACO antibody preincubated with the MBP-ACO protein. b Nuclei stained with PI. c A merged image of a and b. d Young cells at bud tip incubated with anti ACC antibody. e Nuclei stained with PI in young cells at the bud tip. $\mathbf{f}$ A merged image of $\mathbf{d}$ and $\mathbf{e}$. $\mathbf{g}$ Cells at the bud shoot apical meristem incubated with the anti ACC antibody and PI. h, i Leaf primordia showing cells at different stages of the cell cycle incubated with the anti ACC antibody and PI. Bars $=50 \mu \mathrm{m}(\mathbf{a}-\mathbf{f}), 30 \mu \mathrm{m}(\mathbf{g}-\mathbf{i})$ 


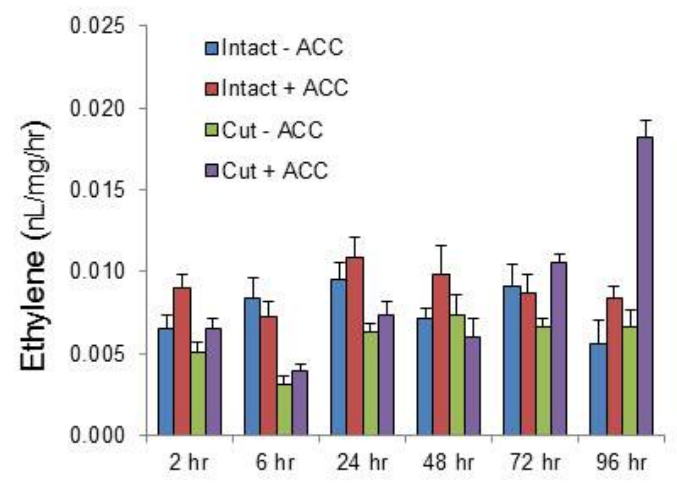


This is an author-produced, peer-reviewed version of this article. The final, definitive version of this document can be found online at

Planta, published by Springer-Verlag. Copyright restrictions may apply. DOI: 10.1007/s00425-013-1887-z.

Fig. 2

Pt EEE98802 ME-FPVISMEKLNGEERAATMEKIKDACENWGFEELLNHGISHEFLDTVERMTKEHYKKCMEQRFKELVASKALDGVQTE 79 At AT1G05010 MESFPIINLEKLNGEERAITMEKIKDACENWGFEECVNHGISLELLDKVEKMTKEHYKKCMEEREKES IKNRGLDSLRSE 80 Ee ACC OXidase ME-FPVINMEKLNGEERAATMAKIKDACENWGFFEILNHGIETEFMDRVESMTKGHYQKCMEQRFKEMVASKGLDSVQTE 79 $\mathrm{Hb}$ CAN85571 ME-FPVINLEKLNGEERASTMAKIKDACENWGEFELLDHGIEPEFLDTVERMTKGHYRKCMEQRFKEMMAGKGLENVQTE 79 Me ABK58140 ME-FPVINLEKLNGEERAATMAKIKDACENWGFEELLNHGIEPEFLDRVESMTKGHYRKCMEQRFKEMVANKGLDAVQTE 79

Pt EEE98802 IKDLDWESTEQLRHLPKSNIAEIPDLDDEYRKVMKEEALKLEKLAEELLDLLCENLGLEKGYLKRAFYGSNGS PTEGTKV 159 At AT1G05010 VNDVDWESTFYLKHLPVSNISDVPDLDDDYRTLMKDEAGKIEKLSEELLDLLCENLGLEKGYLKKVFYGSKR-PTFGTKV 159 Ee ACC Oxidase IKDLDWESTFHIRHLPQSNISEIPDLADDYRKLMKEEAGKLEKLAEELLDLLCENLGLEKGYLKNTFYGSKG-PTEGTKV 158 $\mathrm{Hb}$ CAN85571 IKDLDWESTFYLRHLPESNIAQVPDLDDEYRKVMKEFAAKLEKLAEELLDLLCENLGLEKGYLKKAEYGSRG-PTEGTKV 158 Me ABK58140 IKDMDWESTFF IRHLPDSNLAQLPDLDDEHRAVMKEEAAKLEKLAEDLLDLLCENLGLEKGYLKKAFYGSRG-PTEGTKV 158

Pt EEE98802 SNYPPCPKPDLVKGLRAHTDAGGIILLEQDDKVSGLQLLKDGQWIDVPPMRHS IVVNLGDQLEVITNGKYKSVEHRVIAQ 239 At AT1G05010 SNYPPCPNPDLVKGLRAHTDAGGIILLFQDDKVSGLQLLKDGEWVDVPPVKHS IVVNLGDQLEVITNGKYKSVEHRVLSQ 239 Ee ACC Oxidase SNYPPCPKPDLIKGLRAHTDAGGIILLFQDDKVSGLQLLKDGEWVDVPPMRHS IVVNLGDQLEVITNGKYKSVEHRVVAQ 238

$\mathrm{Hb}$ CAN85571 SNYPPCPKPDLIKGLRAHTDAGGIILLFODDKVSGLOLLKDGOWIDVPPMRHS IVINLGDQLEVITNGKYKSVEHRVVAQ 238 Me ABK58140 SNYPPCPKPDLIKGLRAHTDAGGIILLEQDDRVSGLQLLKDGQWIDVPPMRHS IVVNLGDQLEVITNGKYKSVEHRVVAQ 238

Pt EEE98802 TDG-TRMSVASFYNPGSEAVIYPAPALVEKEAE--EKKN--VYPKFVFDDYMKLYAGLKEQAKEPREEAMKAVETTVN-- 312 At AT1G05010 TDGEGRMS IASFYNPGSDSVIF PAPEL IGKEAEK-EKKE--NYPRFVFEDYMKLYSAVKEQAKEPRFEAMKAMETTVANN 316 Ee ACC Oxidase TDG-TRMSLASFYNPGSDAVIYPAPALLENEAEDDQKKNQLVYPKFVFEDYMKLYAALKFQAKEPREEAMKAVAAV 314 $\mathrm{Hb}$ CAN85571 TDG-TRMS IASEYNPGSDALIYPAPALVEKA.AE--QKKL--VYPKFVEEDYMKLYAGLKFQAKEPREEAMKAVESNVN-- 311 Me ABK58140 TDG-TRMSLASEYNPGSDAVIYPAPALVEKEAE--EKKQ--VYPKEVEEDYMKLYVGLKEQAKEPREEAMKAVENNVN-- 311

Pt EEE98802 LGPIATA

At AT1G05010 VGPLATA 323

Ee ACC Oxidase 314

Me ABK58140 LGPNCYCLIINYY 324 
This is an author-produced, peer-reviewed version of this article. The final, definitive version of this document can be found online at Planta, published by Springer-Verlag. Copyright restrictions may apply. DOI: 10.1007/s00425-013-1887-z.

Fig. 3

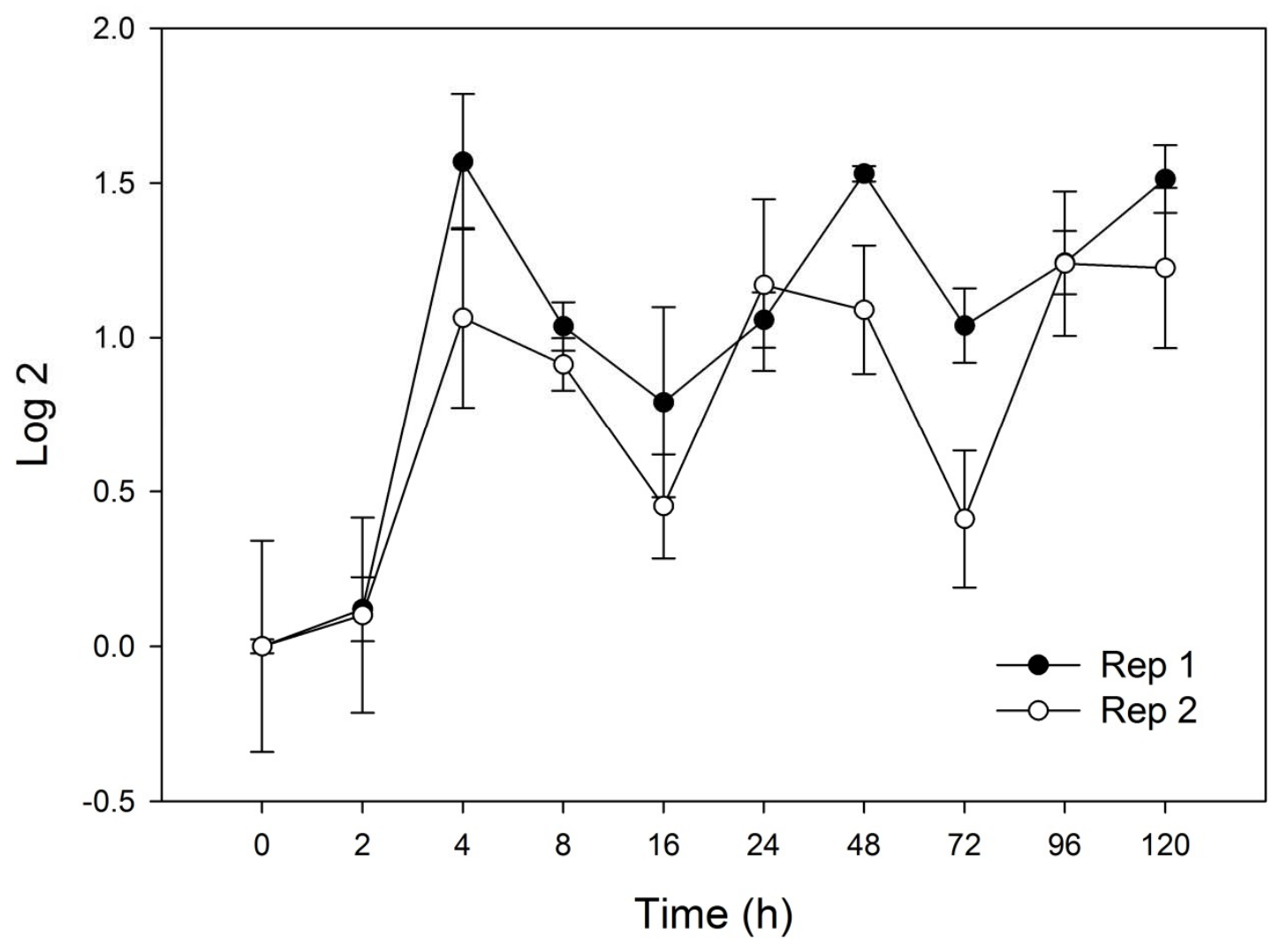


This is an author-produced, peer-reviewed version of this article. The final, definitive version of this document can be found online at Planta, published by Springer-Verlag. Copyright restrictions may apply. DOI: 10.1007/s00425-013-1887-z.

Fig. 4

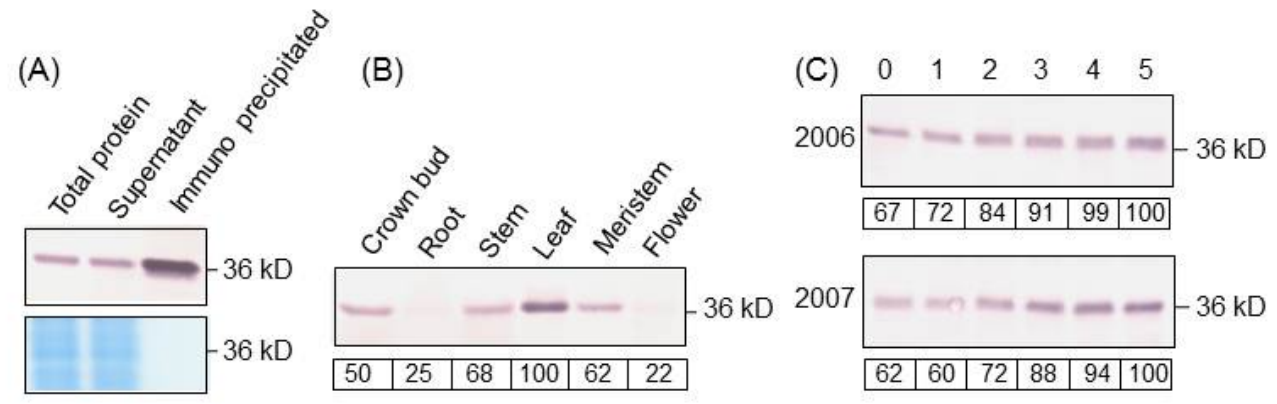


Fig. 5
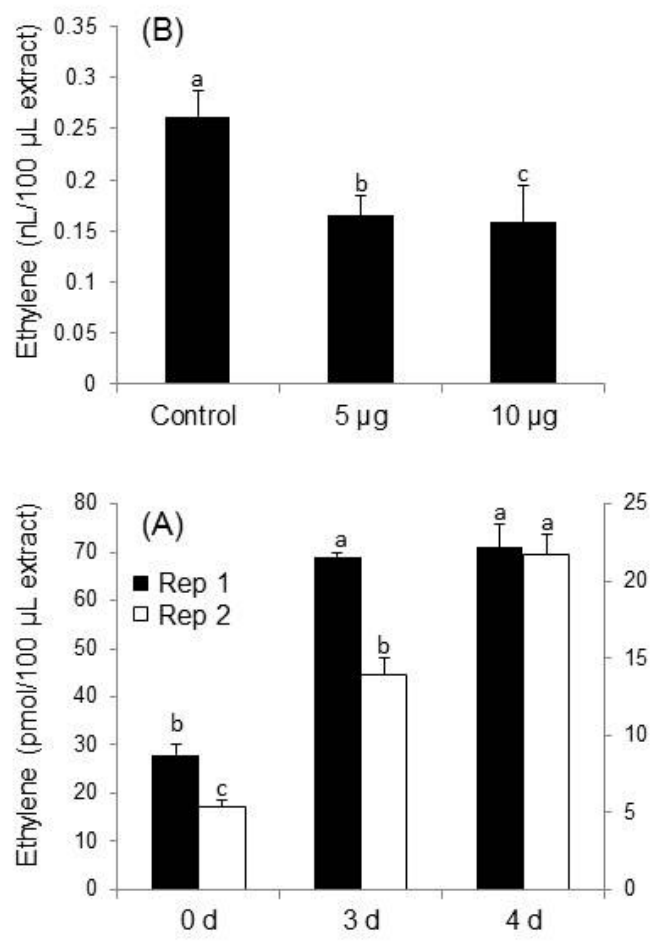

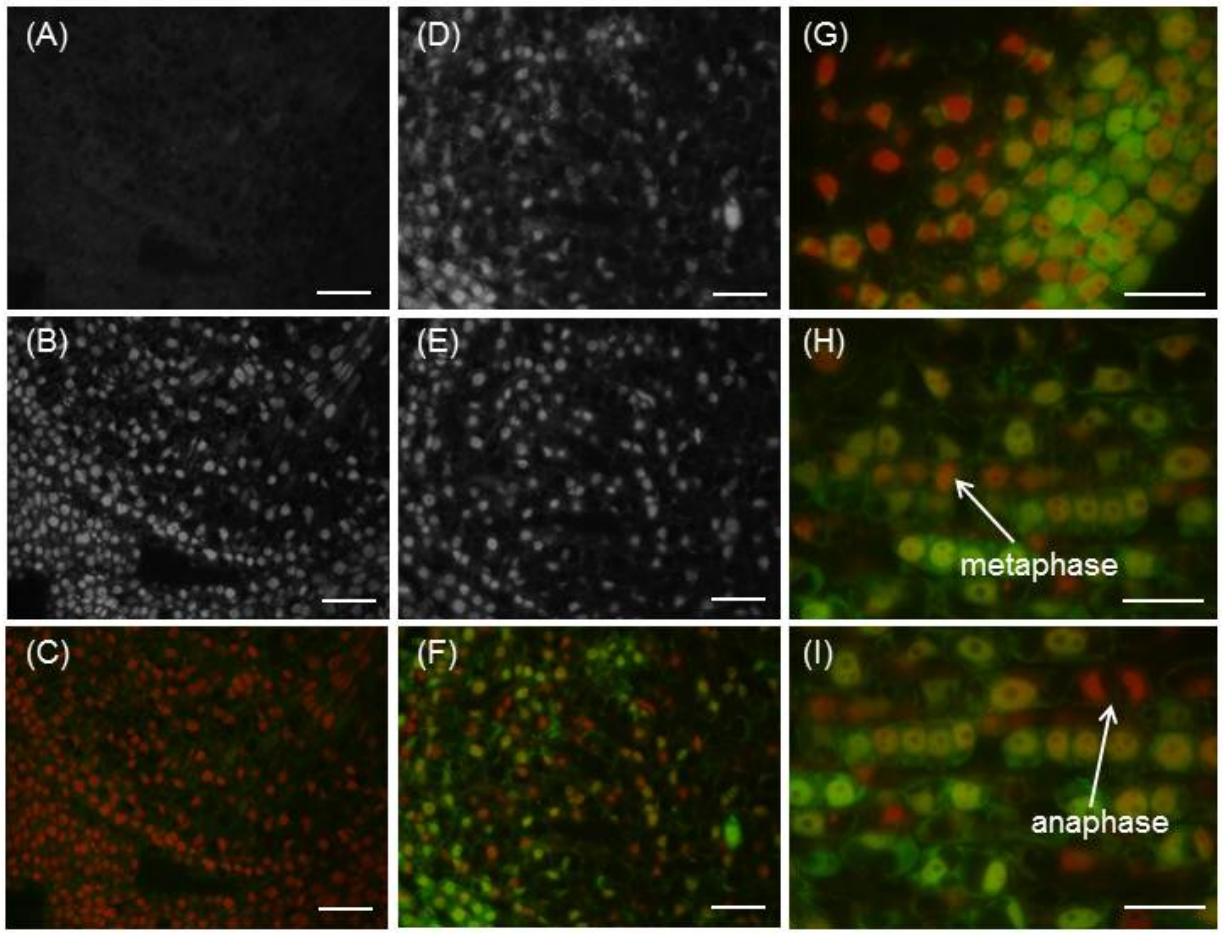